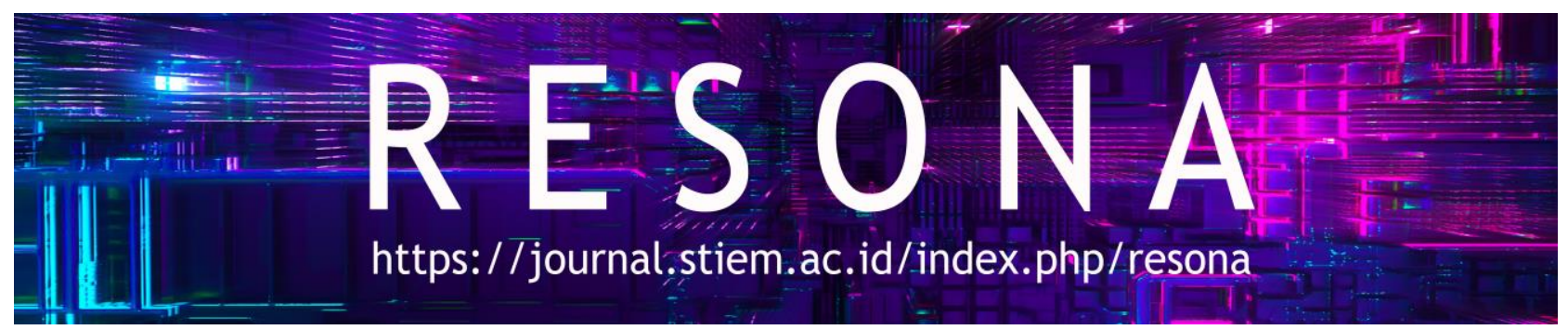

\title{
DIGITALISASI DESA DI DESA CIKOLE LEMBANG
}

\author{
Irland Fardani ${ }^{1}$, Gina Puspitasari Rochman ${ }^{2}$, Lely Syiddatul Akliyah ${ }^{3}$, Hani Burhanuddin ${ }^{4}$ \\ ${ }^{1,2,3,4}$ Universitas Islam Bandung
}

INFO NASKAH

Diserahkan

8 Agustus 2021

Diterima

22 Agustus 2021

Diterima dan Disetujui

29 Desember 2021

Kata Kunci:

Digitalisasi, Desa, Desa Cerdas, Pemetaan.

Keywords:

Digitalization, Village, Smart Village, Mapping.

\section{ABSTRAK}

Desa merupakan salah satu level terkecil dari pemerintahan di Indonesia. Dalam program digitalisasi yang sedang digalakan oleh pemerintah Indonesia, desa merupakan ujung tombak dalam penerapannya. Dalam penerapannya, banyak desa yang tidak terlebih dahulu melakukan kajian kesiapan desa dalam penerapan desa digital. Tujuan dari pengabdian ini adalah menilai kesiapan pemerintah desa dalam penerapan desa digital dan membangun system informasi desa yang berisikan pendataan dan pemetaan pembangunan yang dilakukan oleh desa. Aktivitas yang dilakukan adalah (1) wawancara mendalam dengan pihak perangkat desa, (2) FGD, (3) survey lapangan dan (4) pelatihan system informasi desa. Hasil yang didapatkan dari kegiatan ini adalah (1) penilaian terhadap kesiapan pemerintah desa menerapkan desa digital dilai cukup baik yaitu mendapatkan nilai 3.16 dan (2) system informasi yang berisikan data pembangunan desa. Dari kegiatan ini juga dihasilkan sebuah sistem informasi desa yang menyimpan dan menampilkan kegiatan-kegiatan pembangunan di Desa Cikole.

Abstract. The Village is one of the smallest levels of government in Indonesia. In the digitalization program that the Indonesian government promotes, the Village is one of the spearheads in its implementation. In its application, many villages do not first conduct a village readiness study in the application of digital villages. The purpose of this research is to assess the readiness of the village government in implementing digital villages and building a village information system that contains data collection and development mapping carried out by the Village. The activities carried out were (1) in-depth interviews with village officials, (2) FGDs, (3) field surveys, and (4) village information system training. The results obtained from this activity are (1) an assessment of the village government's readiness to implement a digital village which is considered quite good, namely getting a score of 3.16, and (2) an information system containing village development data. With this program, you can prepare Cikole villages in the application of digital villages. From this activity, a village information system was produced which contain activities that store and display development activities in Cikole Village. 


\section{PENDAHULUAN}

Pembangunan Desa di Indonesia pada dasarnya bertujuan meningkatkan kesejahteraan dan kualitas hidup masyarakat desa melalui pemenuhan kebutuhan dasar, pembangunan sarana prasarana desa, pengembangan potensi ekonomi lokal, serta pemanfaatan sumber daya alam secara berkelanjutan sebagaimana tercantum dalam UU No. 6 Tahun 2014 tentang Desa. Berkaitan dengan hal itu, Pemerintah Jawa Barat menyelenggarakan program Desa Digital yaitu program penyediaan Internet dan Literasi Digital Masyarakat. Program Desa Digital bertujuan untuk menyediakan akses internet di desa yang sebelumnya tidak memiliki koneksi internet sama sekali. Secara konseptual desa digital merupakan sebuah program untuk menjadikan desa sebagai wilayah pembangunan yang memberdayakan masyarakat dengan sarana teknologi informasi yang memadai (Wijaya et al., 2013).

Pada dasarnya, konsep desa digital memiliki dua unsur penting didalamnya yaitu pemberdayaan masyarakat desa dan teknologi informasi (Suyatna et al., 2019). Paradigma pembangunan pedesaan berbasis internet penting dilakukan di tengah perkembangan teknologi informasi dan komunikasi (Muhammad, 2016). Berbagai tulisan mendeskripsikan bahwa dengan adanya pemanfaatan teknologi informasi di Desa dapat meningkatkan partisipasi dan keterbukaan di desa. Dengan adanya sistem desa digital melalui sistem informasi desa akan mempermudah komunikasi dalam suatu desa antara aparat desa dengan warga dibutuhkan suatu media komunikasi.

Dari hasil wawancara kepada beberapa penduduk di Desa Cikole, tergambarkan bahwa kondisi Desa Cikole pada saat ini masih menerapkan sistem konvensional yaitu dengan melakukan pencatatan administrasi desa secara manual atapun offline, menyulitkan warga Desa Cikole untuk mengakses informasi desa. Salah satunya adalah laporan anggaran desa yang sulit diakses oleh para warga-nya. Menurut penelitian yang dilakukan oleh Wardani (Wardani, 2018), dengan adanya sistem informasi desa maka masyarakat akan lebih mudah dalam mengakses perencanaan maupun realisasi anggaran desa.

Lokasi pelaksanaan PKM akan dilakukan pada daerah yang belum mempunyai Sistem Informasi Desa. Objek PKM yabg diutamakan pada kegiatan ini adalah desa binaan LPPM UNISBA yaitu di Cikole Lembang Kabupaten Bandung Barat. Tema kegiatan PKM mengusulkan pembangunan sistem informasi desa. Hal ini pun sudah sejalan dengan program LPPM UNISBA untuk berperan dalam upaya memetakan persoalan dan mencarikan terkait pembangunan desa di Jawa Barat.

Aplikasi sistem informasi desa banyak telah dibuat di beberapa desa di Indonesia yang 
disediakan oleh pemerintah pusat ataupun kabupaten/kota. Hal ini mengindikasikan bahwa aplikasi-aplikasi tersebut dibangun secara top-down yaitu dibangun dari kebutuhan pihak luar bukan dari desa tersebut. Padahal sebuah sistem informasi yang baik berasal dari kebutuhan dari internal desa.

Hasil penelusuran awal di wilayah Desa Cikole, masih terdapat masalah mengenai belum tertatanya arsip dokumen secara sistematis, masyarakat yang sulit untuk mengakses informasi tentang desa, belum tersedianya sistem informasi dan manajemen berbasi komputer dan website desa serta minimnya keterampilan aparatur desa dalam mengelola data berbasis komputer.

Dengan adanya beberapa masalah yang sudah sebutkan sebelumnya, maka kami merancang beberapa solusi seperti yang terlihat pada Gambar 1.Permasalahan pertama yaitu belum adanya sistem informasi desa menjadikan sulitnya mengakses terhadap informasi desa, salah satu solusi untuk memecahkan permasalahan tersebut adalah dengan dikembangkan atau menyediakan sistem informasi menajemen berbasis komputer sehingga dapat mengefisienkan pengarsipan data di desa. Pengembangan sistem informasi desa ini harus melibatkan partispasi masyarakat secara luas, guna menumbuhkan rasa kepemilikan terhadap aplikasi yang dikembangkan serta memfasilitasi semua kebutuhan tentang kegiatan masyarakat. Salah satu contoh rancangan aplikasi sebagai solusi untuk mengakses informasi anggaran dan realisasi dapat dilihat pada Gambar 1.

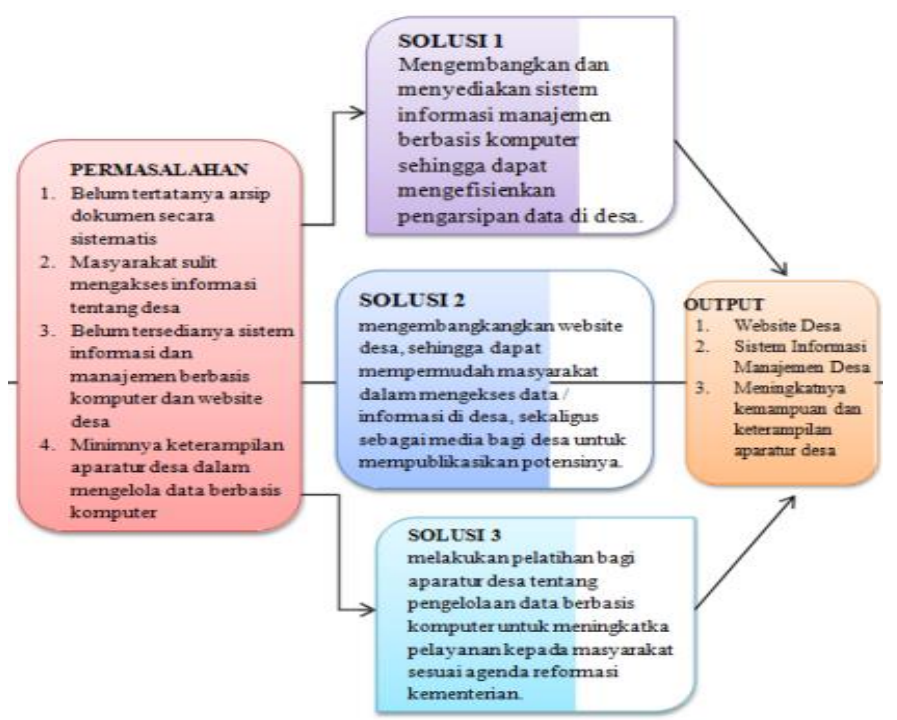

Gambar 1: Solusi dan permasalahan

Untuk permasalahan sulitnya mengakses informasi desa dan belum adanya website desa, solusi yang ditawarkan adalah dengan mengembangkan website desa, sehingga dapat 
mempermudah masyarakat dalam mengakses data dan informasi di desa. Hal ini perlu dilakukan melihat kondisi saat ini yakni dengan adanya trend penyimpanan atau penyampaian informasi berbasis internet. Dengan dipublikasikannya informasi potensi desa diharapkan dapat mengembangkan potensi-potensi yang ada di Desa Cikole.

Dalam permasalah minimnya keterampilan aparatur desa dalam mengeleola data berbasis komputer, solusi yang ditawarkan adalah dengan melakukan pelatihan bagi apatratur desa tentang pengelolaaan data berbasis komputer. Hal ini dilakukan untuk meningkatkan pelayanan kepada masyakarat sesuia dengan program desa digital yang diinisiasi oleh Provinsi Jawa Barat.

\section{METODE}

Bagian metode ini harus dapat menjelaskan metode pengabdian yang digunakan, juga termasuk langkah-langkah/prosedur pelaksanaan pengabdian. Alat, bahan, media atau instrumen pengabdian harus dijelaskan dengan baik. Jika perlu dan penting, ada lampiran mengenai kisi-kisi dari instrumen atau penggalan bahan yang digunakan sekedar memberikan contoh bagi para pembaca.

Waktu kegiatan pengadian in memakan waktu delapan bulan, yaitu dimulai dari bulan Desember 2020 dan berakhir pada bulan Juli 2021. Terget sasaran pengadian adalah Desa Cikole, Kecamatan Lembang, Kabupaten Bandung Barat, Prvonsi Jawa Barat. Untuk mendapatkan informasi tentang digitalisasi desa, dilakukan wawancara mendalam terhadap perangkat desa, kegiatan Focus Group Discussion, survey dan workshop. Urutan kegiatan yang dilakukan selama pengabdian kepada masyarakat dapat dilihat pada gambar 2 .

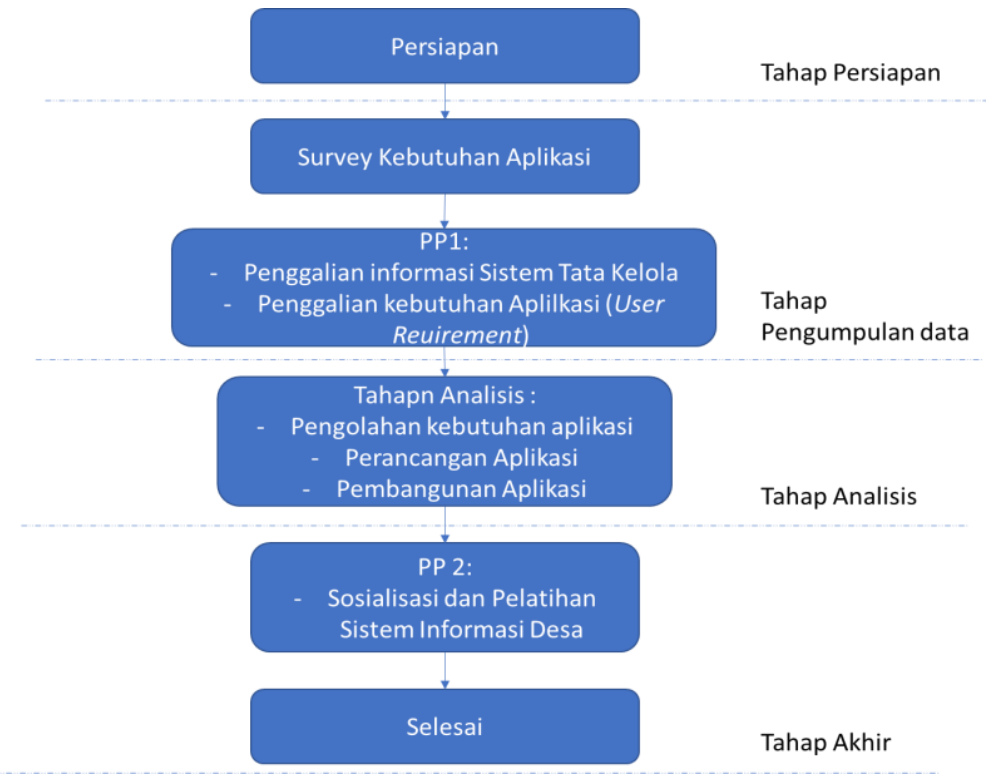

Gambar 2: Urutan Kegiatan Pengabdian Kepada Masyarakat. 
Berdasarkan bagan diatas, dapat disimpulkan terdapat 4 (empat) tahapan dalam kegiatan PKM ini, yaitu :

a. Tahap Persiapan

Tahap persiapan ini meliputi kosolidasi tim, persiapan teknis pelksanaan Pengabdian Kepada Masyarakat (PKM), persiapan survey, Persiapan PP (Participatory Planning) dan persiapan pada mitra yaitu perangkat desa dan masyarakat desa cikole.

b. Tahap Pengumpulan Data

Tahap pengumpulan data secara garis bear meliputi survey keubutuhan kebuthan aplikasi baik secara sekunder maupun wawancara kepada masyarakat, dan kegiatan PP (Participatory Planning) ke satu yang terdiri dari penggalian sistem tata Kelola administrasi pemerintahan di desa serta kebutuhan aplikasi yang diinginkan oleh masyarakat atau yang lebih sering dikenal sebagai User Requirement.

Metode yang digunakan dalam tahapan pengumpulan data ini adalah :

1) Identifikasi Sistem

a) Dilakukan pengamatan terhdap sistem tata Kelola pemerintahan eksisting berupa bagaimana sistem perencanaan anggaran desa serta pencatatan realisasi anggaran desa.

b) Dilakukan penyebaran kuisioner terhadap kebutuhan sistem informasi desa kepada masyarakat desa cikole. Hal ini bertujuan untuk penjaringan awal kebutuhan akan adanya informasi pada aplikasi yang akan dibangun.

c) Informasi yang dibutuhkan :

Tabel 1: Komponen dan Varibel yang dibutuhkan

\begin{tabular}{|l|l|l|}
\hline NO & \multicolumn{1}{|c|}{ Komponen } & \multicolumn{1}{|l|}{ Variabel } \\
\hline 1 & Administrasi Desa & a. Letak administratf \\
& & b. Status pemerintahan \\
& & c. Nama kepala desa \\
& & d. Alamat kantor \\
\hline 2 & Laporan & a. Tahun \\
& Anggaran Desa & b. Rencana \\
& tahunan & c. Realisasi \\
& & d. Koordinat Lokasi (GPS) \\
\hline 3 & Lokasi Geografi & a. Foto \\
\hline
\end{tabular}


2) Focus group discussion (FGD) dengan pendekatan Perencanaan Partisipatif (Participatory Planning-PP)

Participatory planning adalah sebuah pendekatan yang melibatkan seluruh komponen dari masyarakat dalam menyusun strategi dan proses pengelolaaan sebuah wilayah. Participatory planning mempunyai tujuan untuk mengharmonisasi semua partisipan dan juga mencegah adanya konflik atara masyakat. Pendekatan ini menekankan pada pembelajaran bersama antara mitra dan tim PKM di dalam merencanakan suatu intervensi yang tepat. Pendekatan ini bersifat experiential sehingga pada praktiknya disesuaikan dengan kondisi dan karakteristik mitra (Chambers, 1994). Pendekatan ini kami gunakan sebagai proses pembelajaran sehingga dapat meningkatkan partisipasi, mengembangkan kemampuan analisis, dan juga mendorong sikap saling menghargai pendapat orang lain. Untuk itu, dalam prosesnya, tim akan berperan sebagai fasilitator. Metode PP yang dilakukan pada tahap pertama ini adalah :

a) Pengenalan situasi kondisi dan permasalahan mengeni tata Kelola pemerintahan

b) Informasi mengenai informasi yang diinginkan oleh masyarakat untuk diakses

c) Data data anggaran keuangan desa tiap tahun.

3) Tahap Analisis

Tahap analisis melitputi pengimplementasian sistem tata Kelola administrasi pada desa serta kebutuhan aplikasi yang diinginkan oleh masyarakat. Seteleh diolah dari hasil tersebut, masuk kedalah tahapan pembangunan aplikasi atau tahapan coding. Setelah dilakukan pembangunan aplikasi atau coding, dilakukanlah testing aplikasi untuk mengantisipasi error yang mungkin masi muncul pada aplikasi.

Dari hasil PP tahap ke 1 dilakukanlah pendokmentasian terhadap 4 sistem tata kelola dan kebutuhan masyarakat. Dokumen ini digunakan utnuk Menyusun aplikasi dengan menggunakan metode agile development seperti yang terlihat pada Gambar 3. Agile Development Methods adalah sekelompok metodologi pengembangan perangkat lunak yang didasarkan pada prinsip-prinsip yang sama atau pengembangan sistem jangka pendek yang memerlukan adaptasi cepat dari pengembang terhadap perubahan dalam bentuk apapun. 


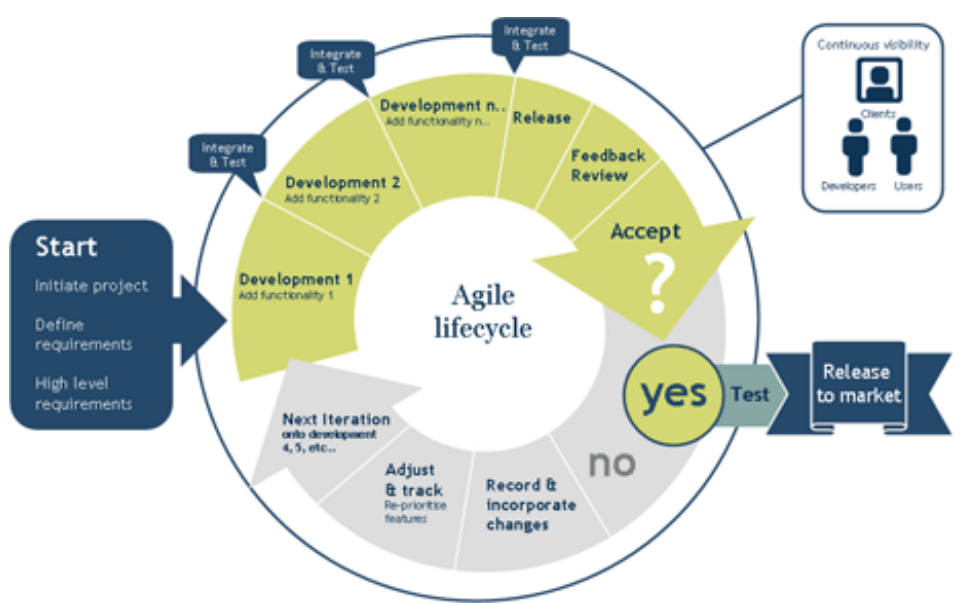

Gambar 3: Skema Pengembagan Aplikasi Dengan Agile Methode

Dalam proses pembangunan aplikasi sistem informasi desa pada PKM ini, memanfaatkan teknologi Sistem Informasi Geografis (SIG). Penggunaan teknologi SIG terbukti sangat efesien untuk memetakan dengan detail Cultural Heritage (Hadjimitsis et al., 2013). Salah satu fitur dari SIG yang dapat digunakan adalah bentuk Geodatabase, nantinya akan menggabungkan kondisi anggaran desa dengan lokasi lokasi realisasi anggaran yang telah dilakukan, dengan menggunakan Geodatabase ini dapat mempermudah sistem untuk melakukan query dan menampilkan informasi (Malinverni et al., 2019). Langkah selanjutnya dalam pengembangan aplikasi adalah pengujian aplikasi dan quality assurance, tahapan ini meliputi beberapa tahapan yaitu test aplikasi (try and error), sistem test, stress test, security test dan user acceptance test. Seluruh proses dan hasil analisis dijelaskan melalui FGD dan workshop untuk kemudian dilakukan perbaikan sesuai dengan kebutuhan dan kapasitas aparatur desa.

4) Tahap Akhir

Tahap akhir melalui kegiatan Participatory Planning (ke-2), untuk melakukan sosialisasi aplikasi dan pelatihan sistem informasi desa.

Metode pelaksanaan tahap akhir adalah dengan melakukan PP tahap ke 2 yaitu melakukan pelatihan kepada masyarakat dengan sisten Training Of Trainer (TOT), yaitu dengan melakukan pelatihan kepada sekelompok masyarakat yang nantinya akan menyebarkan kemampuannya untuk melatih warga lain. 


\section{HASIL DAN PEMBAHASAN}

a. Kegiatan Focus Group Discussion dan Survey

Untuk mendapatkan informasi mengenai system tatakelola pemerintah dan keinginan warga masyarakat desa cikole. Maka dilakukanlah kegiatan Focus Group Dissusion, kegiatan ini dihadiri oleh perangkat desa serta perwakilan dari masyarakat seperti yang dapat dilihat pada gambar 4 .

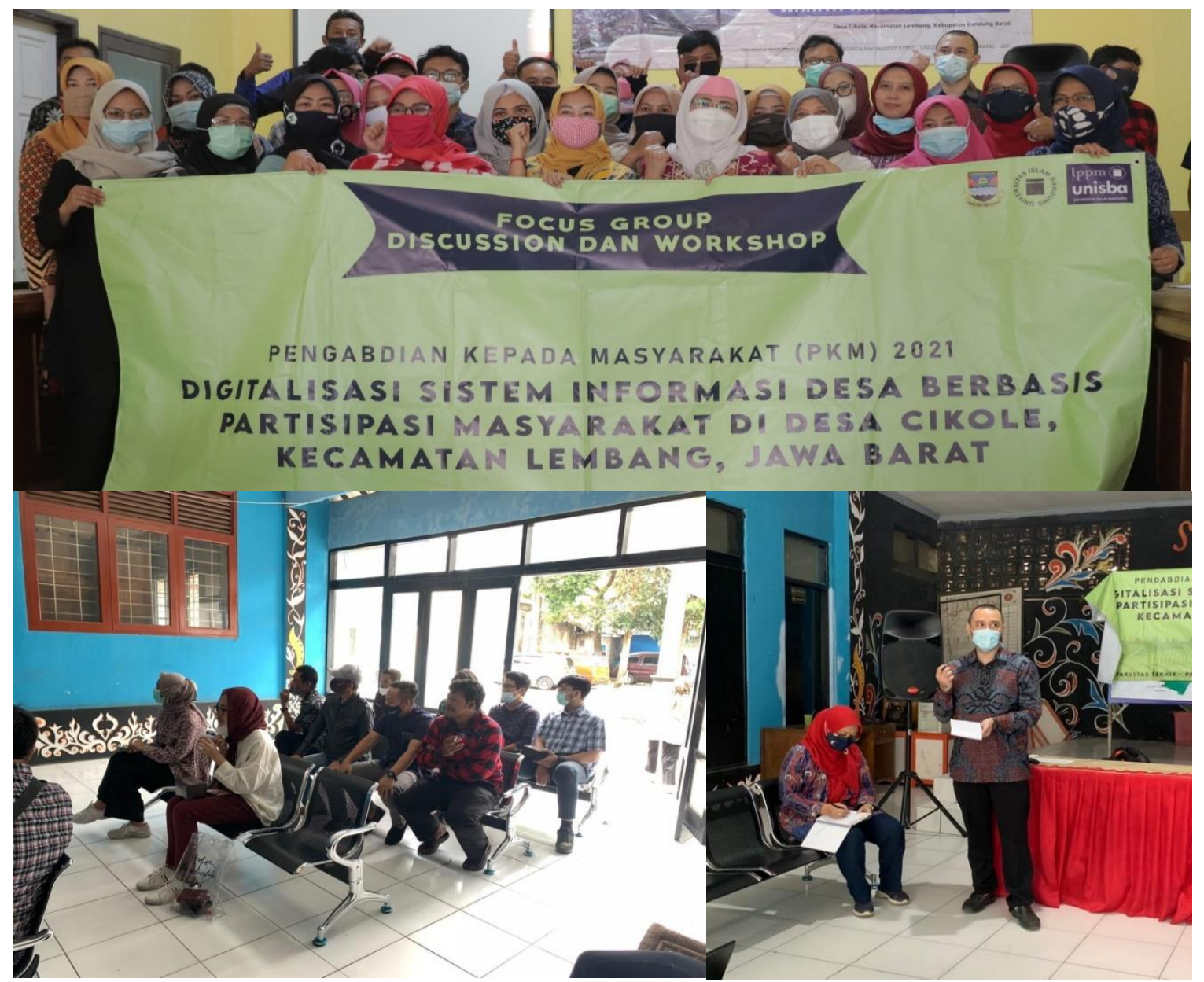

Gambar 4 Kegiatan Focus Group Discussion di Desa Cikole Sumber : Dokumentasi Pribadi

Dari kegiatan ini didapatkan beberapa masukan dari warga, yaitu :

1) Dengan adanya rencana program digitalisasi ini dapat mempromosikan potensi yang ada di desa dan berimpak terhadap perkonomian desa.

2) Program digitalisasi diharapkan meningkatkan pelayanan pemerintah desa.

3) Diperlukan peningkatan Sumber Daya Manusia, baik apparat desa atau warga dalam penerapan digitalisasi desa 
4) Adanya program yang terus berkesinambungan dalam pengembangan desa digital.

5) Masyarkat desa menginginnkan keterbukaan data dan kegiatan pembangunan yang dilakukan oleh desa.

Dari point-point yang disampaikan warga dan mayarakat ini, dapat diwadahi dalam kegiatan ini yaitu dengan kegiatan peneilai kesiapan pemerintah desa dalam penerapan desa digital dan pengembangan system informasi pembangunan di desa cikole. Kegiatan selanjutnya adalah melakukan survey potensi desa dan lokasi pembangunan yang ada di desa Cikole. Target kegiatan ini adalah mendapatkan database berupa koordinat serta deskripsi lokasi-lokasi yang di survey, untuk kegiatan survey dapat terlihat pada gambar 4 .

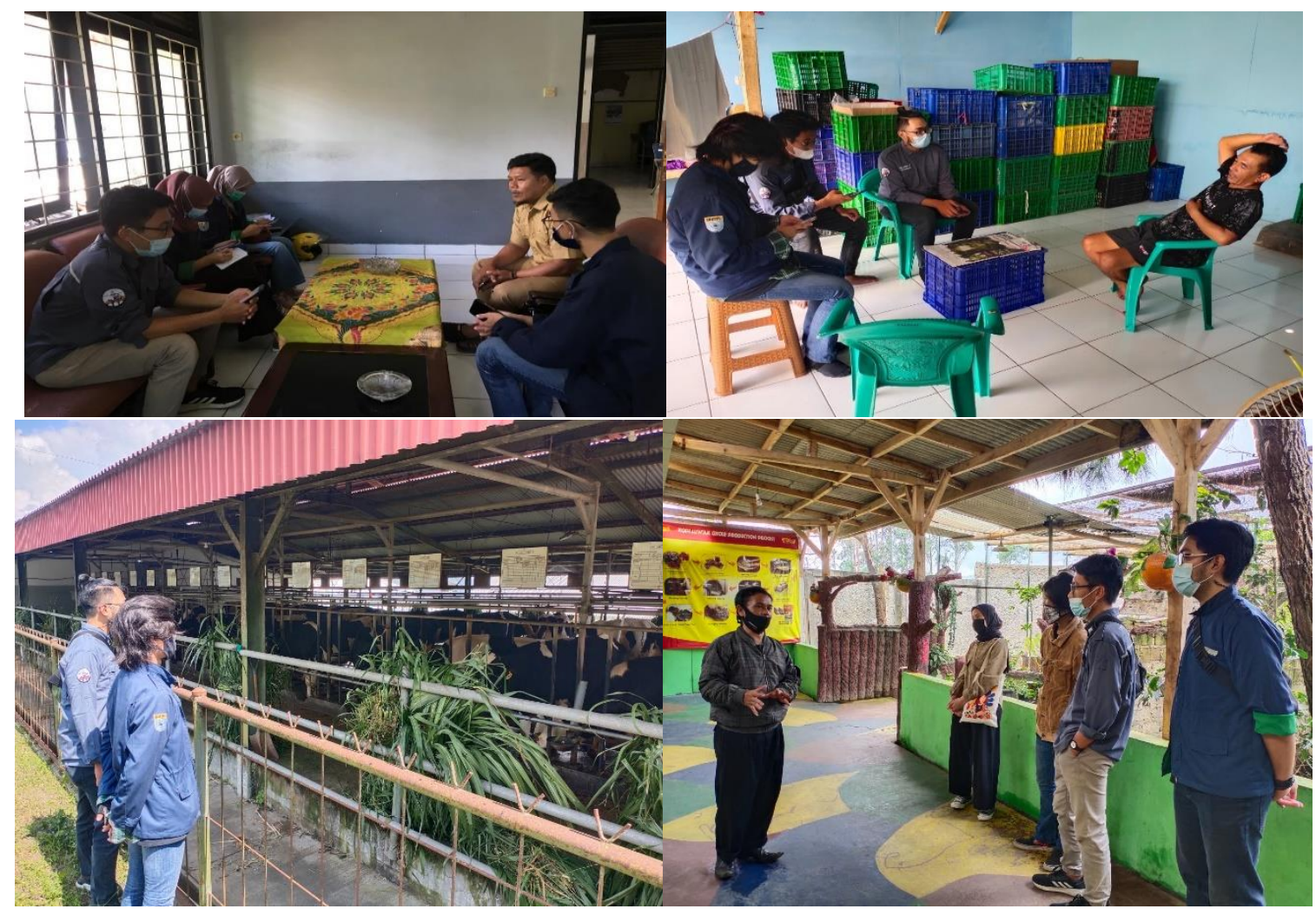

Gambar 5: Foto Kegiatan Survey di Desa Cikole

Sumber : Dokumentasi Pribadi

\section{b. Penilaian Kesiapan Desa Digital}

Salah satu bentuk dari kegiatan digitalisasi pemerintahan desa adalah penerapan Smart government. Smart governance adalah tentang mendesain ulang tata pemerintahan yang demokratis formal dan mempertahankan prinsip-prinsip demokrasi yang dikembangkan secara historis dan ekonomis. Smart governance terdiri atas tiga bagian, yatu keikutsertaan masyarakat didalam penentuan keputusan secara langsung ataupun tidak langsung, peningkatan jumlah dan kualitas layanan publik, serta adanya database yang terstruktur dan 
tertata baik didalaam penyimpanan data dan informasi terkait dengan layanan publik. Setelah melakukan analisis, Desa Cikole belum bisa mencapai indikator Smart Governance seperti yang diharapkan karena tidak adanya pahaman yang mendalam mengenai teknologi

Tabel 2

Analisis Indikator Smart Governance Desa Cikole

\begin{tabular}{|c|c|c|c|c|c|}
\hline No & Dimensi & Pertanyaan & Jawaban & Skor & Nilai \\
\hline \multirow[t]{3}{*}{1} & \multirow[t]{3}{*}{$\begin{array}{l}\text { Partisipasi } \\
\text { Publik }\end{array}$} & $\begin{array}{l}\text { Ketersediaan wadah dalam } \\
\text { menampung aspirasi } \\
\text { masyarakat untuk } \\
\text { disampaikan ke pihak } \\
\text { pemerintah desa }\end{array}$ & $\begin{array}{l}\text { Masyarakat berpartisipasi secara aktif } \\
\text { dalam menyuarakan aspirasi yang } \\
\text { dilakukan secara offline }\end{array}$ & 4 & \multirow{3}{*}{3.75} \\
\hline & & $\begin{array}{l}\text { Partisipasi masyarakat dalam } \\
\text { pelaksanaan musrenbang }\end{array}$ & $\begin{array}{l}\text { Masyarakat yang berpartisipasi dalam } \\
\text { pelaksanaan musrenbang diwakilkan } \\
\text { oleh beberapa elemen/kalangan yang } \\
\text { ada seperti ketua RT, ketua RW, } \\
\text { kepala Dusun serta menyuarakan } \\
\text { aspirasinya yang telah dihimpun dari } \\
\text { seluruh masyarakat }\end{array}$ & 4 & \\
\hline & & $\begin{array}{l}\text { Penjaringan aspirasi secara } \\
\text { interaktif pada saat } \\
\text { pengambilan keputusan }\end{array}$ & $\begin{array}{l}\text { Penjaringan aspirasi secara interaktif } \\
\text { pada saat pengambilan keputusan } \\
\text { atntara pihak desa dan juga } \\
\text { masyarakat dikatakan sedang dengan } \\
\text { perkiraan 41-60\% karena pada setiap } \\
\text { kegiatan yang diadakan oleh desa } \\
\text { masyarakat yang berpartispasi } \\
\text { diwakilkan oleh ketua RT/ketua } \\
\text { RW/kepala Dusun dan hanya } \\
\text { sebagian masyarakat }\end{array}$ & 3 & \\
\hline \multirow[t]{2}{*}{2} & \multirow[t]{2}{*}{$\begin{array}{l}\text { Pelayanan } \\
\text { Publik }\end{array}$} & $\begin{array}{l}\text { Pelayanan publik yang } \\
\text { tersedia berjalan sesuai } \\
\text { dengan persyaratan dan } \\
\text { kurun waktu yang telah } \\
\text { ditetapkan }\end{array}$ & $\begin{array}{l}\text { Pelayanan publik yang tersedia di } \\
\text { desa berjalan sesuai dengan } \\
\text { persyaratan dan kurun waktu yang } \\
\text { telah ditetapkan dan pelayanan sesuai } \\
\text { jam operasional }\end{array}$ & 4 & \multirow[t]{2}{*}{2.75} \\
\hline & & $\begin{array}{l}\text { Sistem informasi kebijakan } \\
\text { pemerintah (Perda dan } \\
\text { Peraturan Kepala Daerah) } \\
\text { dapat diakses masyarakat }\end{array}$ & $\begin{array}{l}\text { Pemdes tidak memiliki website } \\
\text { sehingga masyarakat tidak dapat } \\
\text { secara mudah mengakses informasi } \\
\text { mengenai kebijakan pemerintah }\end{array}$ & 1 & \\
\hline
\end{tabular}




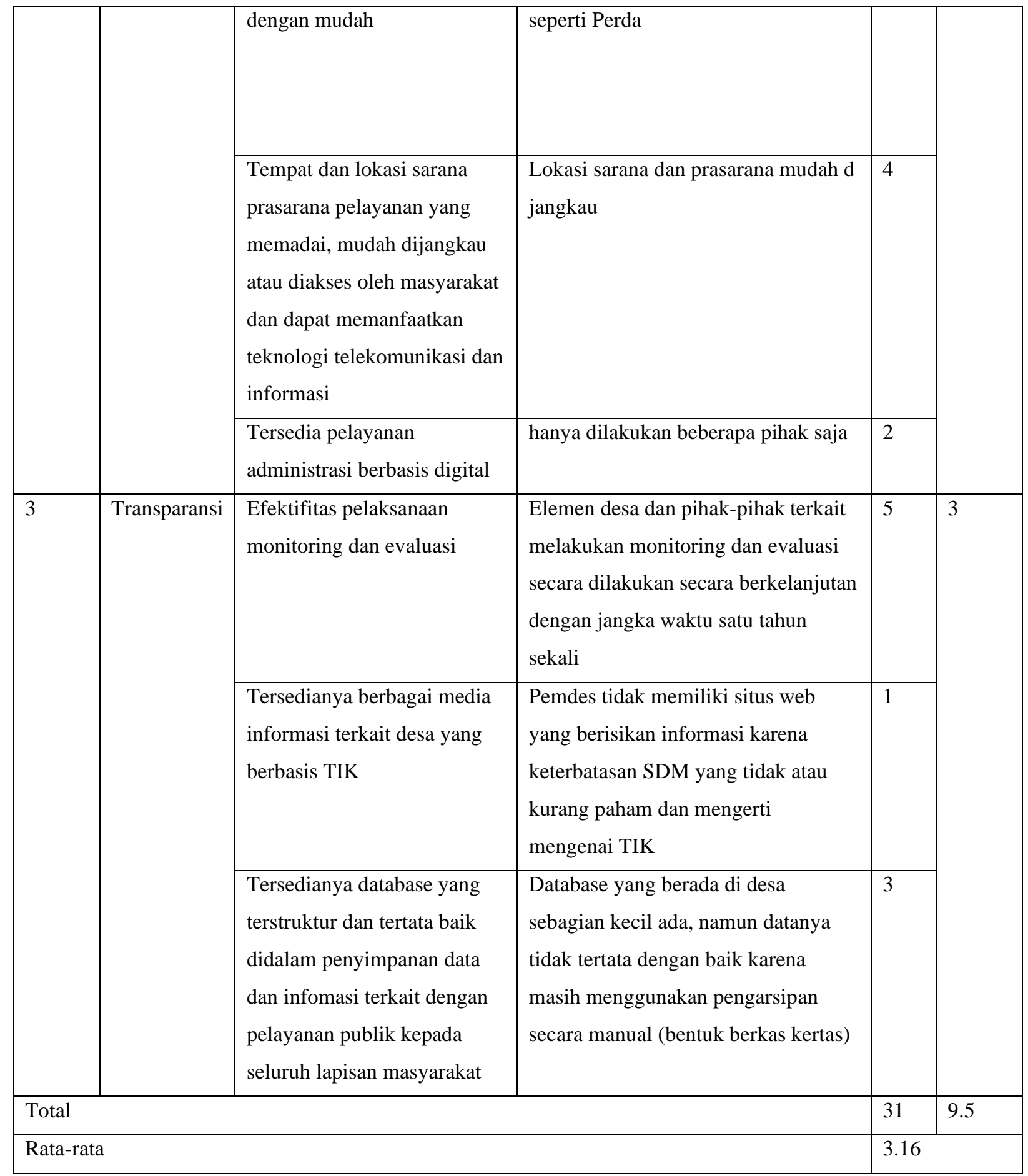

Berdasarkan analisis indikator Smart Governance, Desa Cikole memiliki nilai 3.16 dari skala maksimalnya 5. Hal ini menunjukan bahwa smart government di Desa Cikole belum terbentuk, namun dengan level yang sekarang bisa dijadikan modal yang baik untuk pengembangan smart Government di Desa Cikole 
c. Website Sistem Informasi Desa

Salah satu keluaran dari kegiatan ini adalah Website Sistem Informasi Desa yang akan menjadi sebuah database kegiatan pembangunan di Desa Cikole. Website Sistem Informasi Desa Cikole dapat dikases pada halaman http://188.166.207.47:81/ . Tampilan awal-nya dapat dilihat pada gambar dibawah ini.

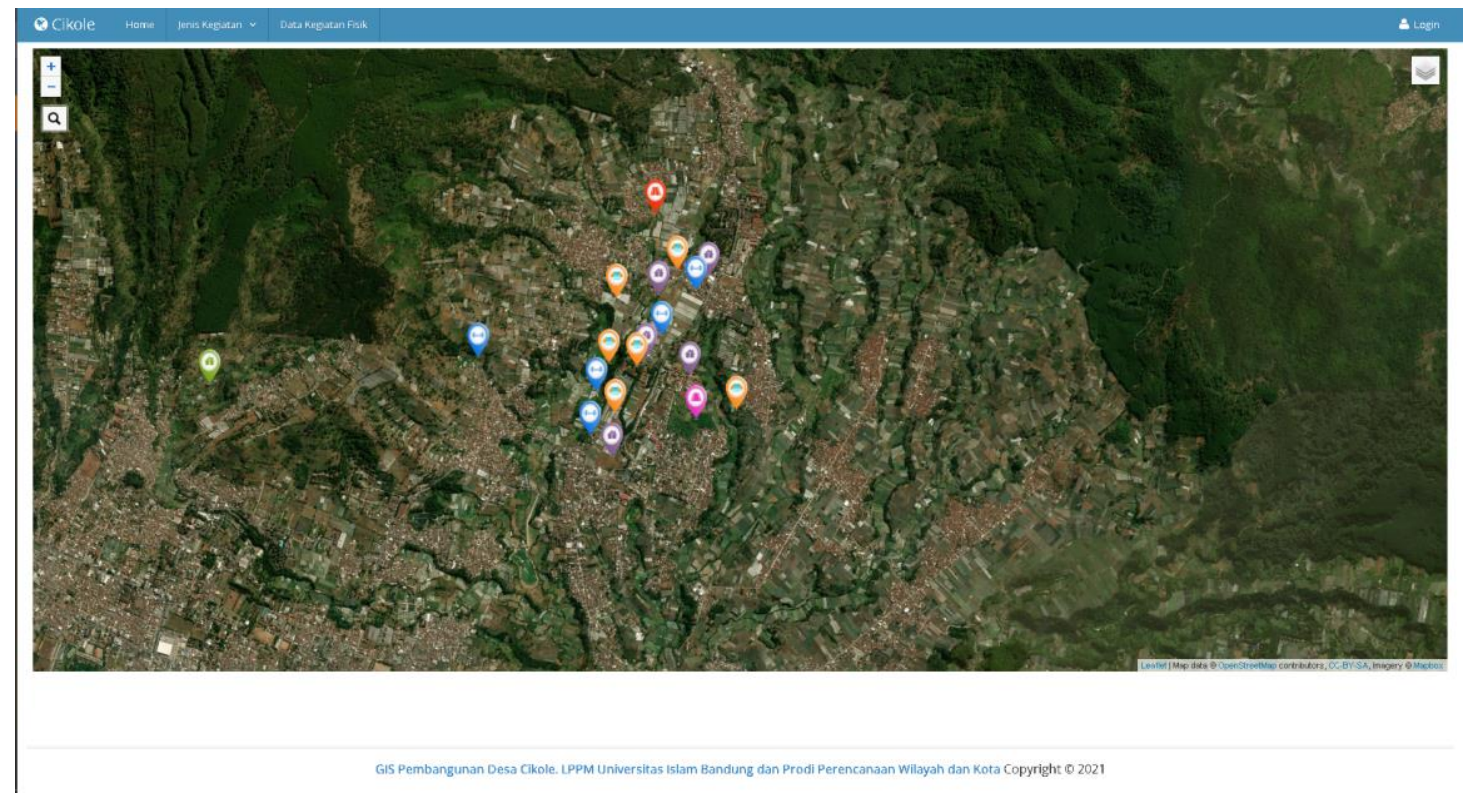

Gambar 6: Tampilan Halaman Muka Website Sistem Informasi Desa Cikole

Pada Sistem Informasi Desa ini ada beberapa menu yang bisa diakses yaitu, tampilan peta, menu login, menu tahun, menu sumber dana, menu kegiatan fisik, menu gallery dan menu user seperti yang dapat dilihat pada gambar dibawah ini.

\begin{tabular}{|c|c|c|c|c|c|c|}
\hline Halaman Admin & Jenis Kegiatan & Tahun & Sumber Dana & Kegiatan Fisik & Gallery & User \\
\hline
\end{tabular}

Gambar 7: Tampilan menu pada Website Sistem Informasi Desa Cikole

Untuk menu peta, berisikan sebaran kegiatan pembangunan desa yang telah diinputkan terlebih dahulu. Sebaran kegiatan desa disimbolkan dalam bentuk titik, kemudian jika diklik akan muncul keterangan detail mengenai kegiatan pembangunan tersebut. Menu peta dapat dilihat pada gambar dibawah ini. 

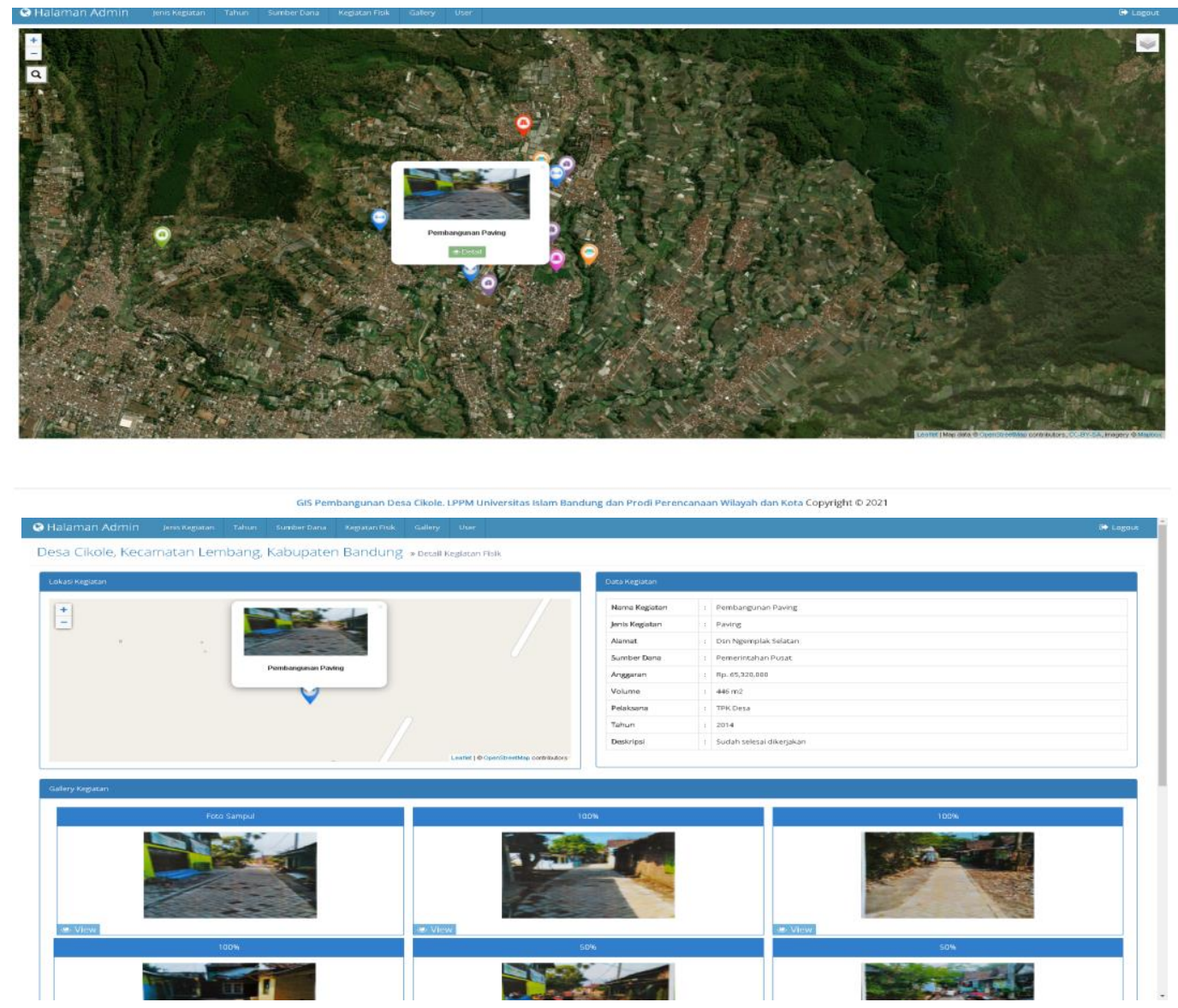

Gambar 8: Menu Tampilan Peta dan Detail informasi

Menu lainnya adalah menu login, menu login berfungsi untuk membatasi akses informasi tertentu yang dapat dilihat secara umum. User dan password setiap pengguna dapat ditambahkan melalui menu registrasi user. Dalam menu tahun, pengguna dapat terus menambahkan tahun kegiatan, hal ini dimaksudkan agar sistem dapat terus digunakan meskipun tahun terus bertambah. Menu lainnya adalah menu sumber dana, menu ini dimaksudkan agar jika adanya nomenklatur sumber dana baru, pengguna dapat menambahkan kedalam sistem. Menu kegiatan lainnya adalah penambahan kegiatan fisik, pada menu ini dapat ditambahkan atau dikurangi naman ama kegiatan yang ada didalam wesite. Menu terakhir adalah menu gallery, dalam menu ini user dapat menambahkan foto foto kegiatan. 


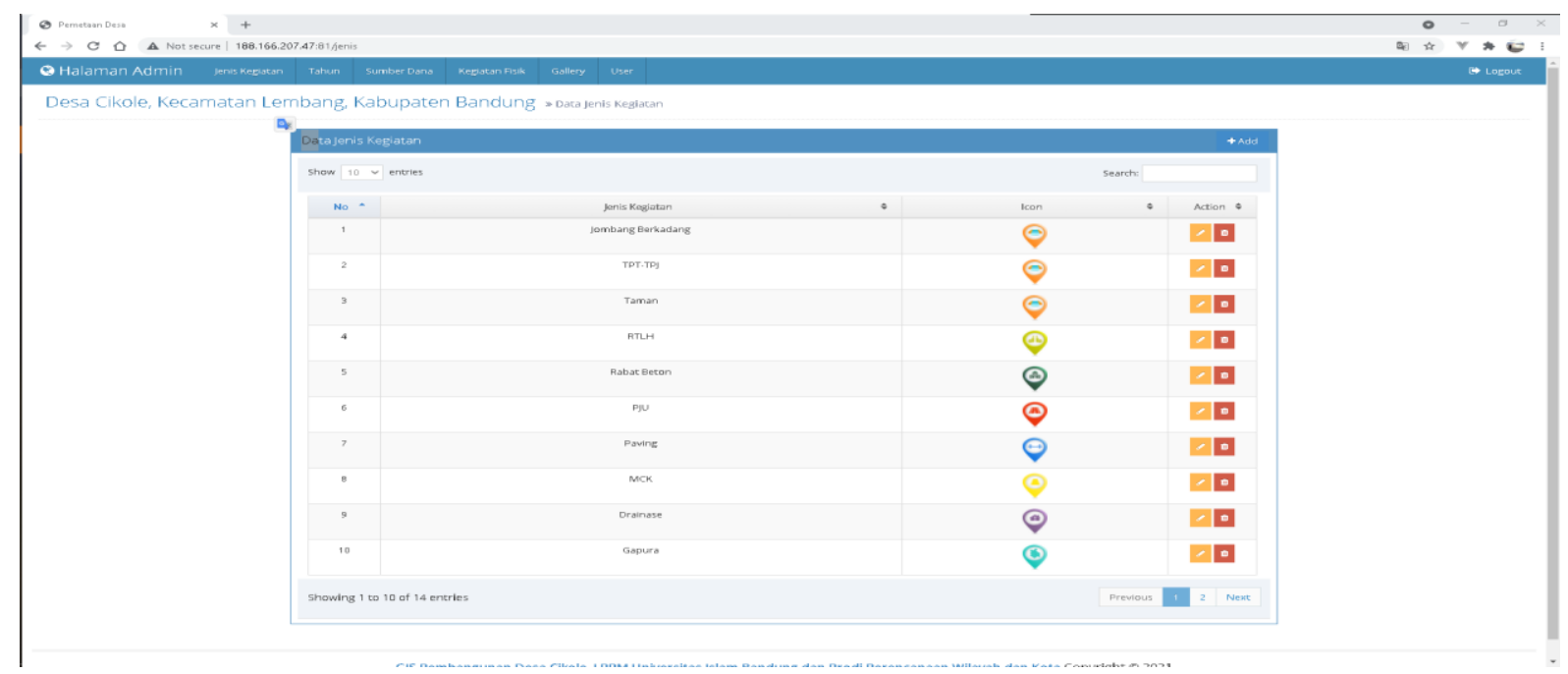

Gambar 9: Menu Jenis Kegiatan

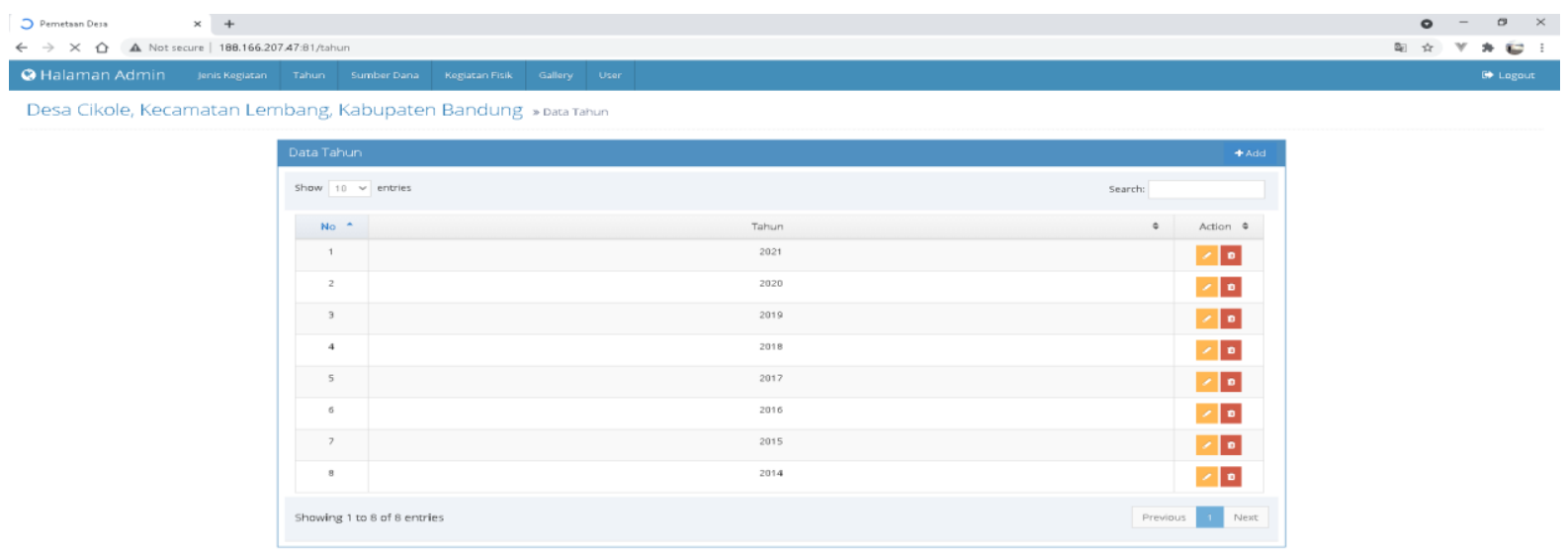

Gambar 10: Menu Tahun

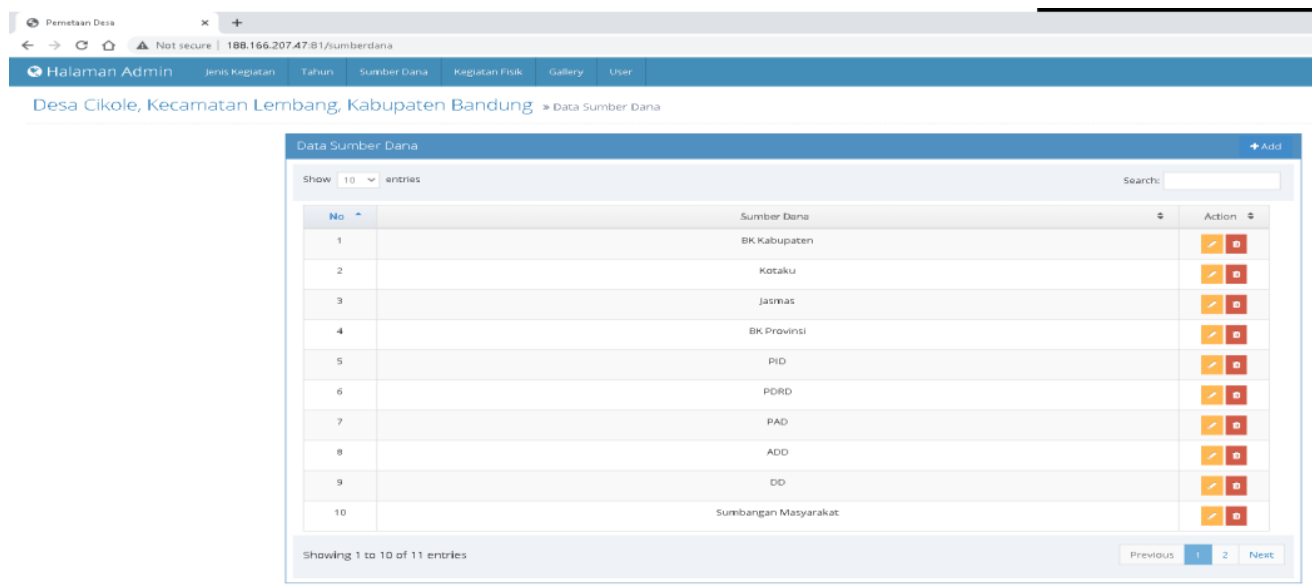

Gambar 11: Menu Sumber Dana 


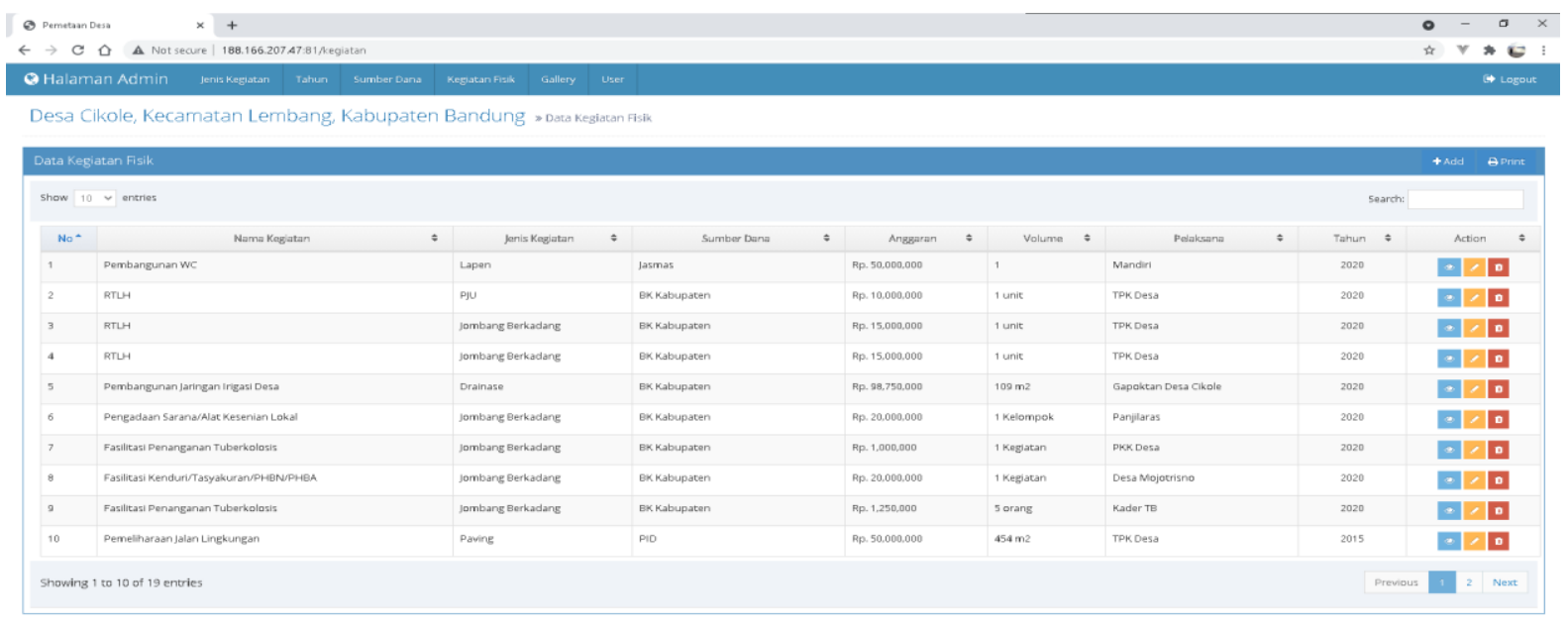

Gambar 12:: Menu Kegaiatan Fisik

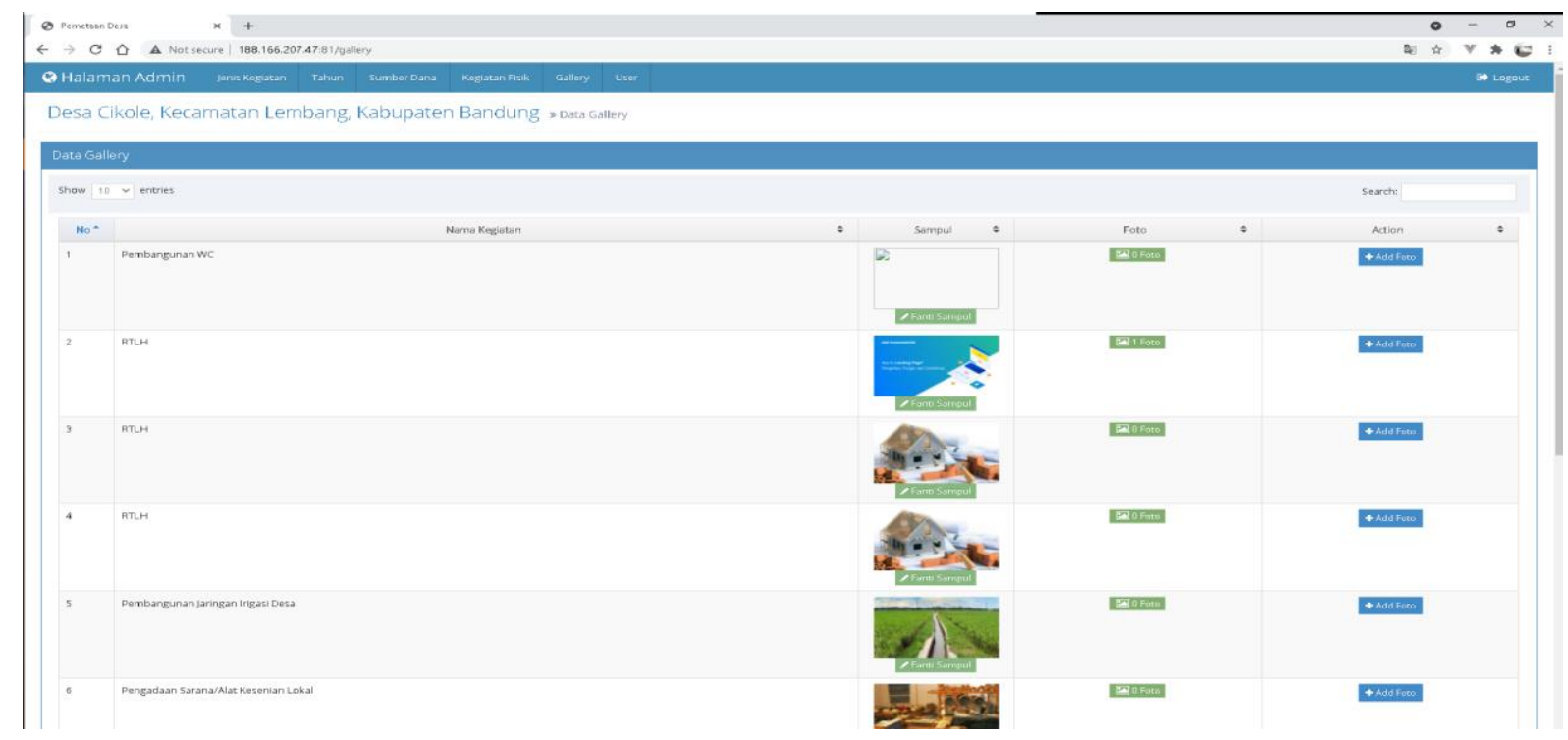

Gambar 13:: Menu gallery

Dikarenakan kondisi di Jawa Barat pada umumnya dan Di Desa Cikole pada khusunya, pada saat kegiatan pelatihan system informasi desa ini masi dalam kondisi Pemberlakuan Pembatasan Kegiatan Masyarakat level 4, maka sosialisasi atau pelatihan system informasi dilakukan via online / zoom. Peserta pelatihan diwakili oleh perangkat desa dan warga desa cikole. 


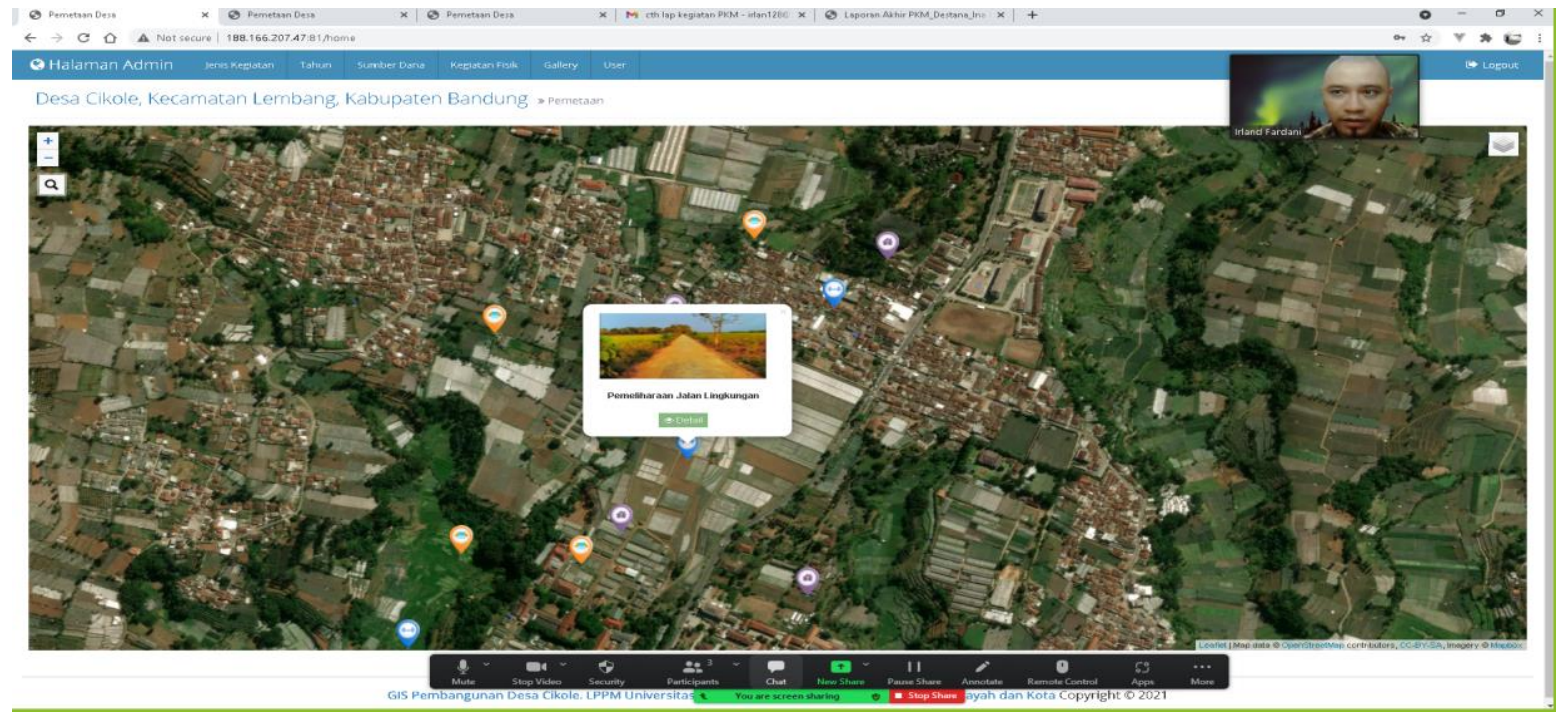

Gambar. 14: Kegiatan Sosialisasi melalui online / zoom

\section{SIMPULAN}

Kegiatan digitalisasi system informasi desa berbasis partisipasi masyarkat di desa cikole, memberikan dampak positif kepada mitra yang terlihat. Dari hasil FGD yang didapat, masukan-masukan warga mengenai program digitalisasi akan dimasukan kedalam kegiatan desa. Mitra tampak antusias mengikuti pelatihan dalam kegiatan FGD maupun pelatihan system informasi yang dikembangkan oleh tim pengabdi. Berdasakan hasil kegiatan pengabdia, maka dapat disimpulkan sebagai berikut :

a. Kondisi kelembagaan di Desa Cikole menunjukan bahwa perangkat desa belum optimal dalam melayani masyarakat Desa Cikole.

b. Kesiapan Desa Cikole untuk menerapkan Desa Digital dinilai cukup baik yaitu mendapatkan nilai 3.16 dari skala penilaian 5. Hal ini berarti desa cikole mempunyai peluang yang besar untuk menjadikan desa-nya berbasis digital.

c. Dari aspirasi beberapa aspirasi masyarakat, mengusulkan bahwa perlu adanya promosi mengenai potensi desa cikole ke masyarakat luar.

d. Dengan adanya sistem informasi desa cikole, kegiatan pembangunan desa dapat management dengan baik serta warga masyarakat dapat melihat pembangunan apa saja yang telah dilakukan di desa. 


\section{DAFTAR PUSTAKA}

Chambers, R., 1994. Participatory Rural Appraisal (PRA): Challenges, Potentials and Paradigm*, World Development.

Hadjimitsis, D., Agapiou, A., Alexakis, D., Sarris, A., 2013. Exploring natural and anthropogenic risk for cultural heritage in Cyprus using remote sensing and GIS. Int. J. Digit. Earth 6, 115-142. https://doi.org/10.1080/17538947.2011.602119

Malinverni, E.S., Chiappini, S., Pierdicca, R., 2019. A Geodatabase for Multisource Data Management Applied to Cultural Heritage: The Case Study of Villa Buonaccorsi's Historical Garden. ISPRS Ann. Photogramm. Remote Sens. Spat. Inf. Sci. 42, 771776. https://doi.org/10.5194/isprs-Archives-XLII-2-W11-771-2019

Muhammad, B., 2016. Pembangunan Pedesaan Berbasis Teknologi Informasi Dan Komunikasi (Studi pada Gerakan Desa Membangun). J. Risal. 27, 62-67.

Suyatna, R., Madya, W.A., Pengembangan, B., Daya, S., Daerah, M., Banten, P., 2019. Desa Digital sebuah Konsep Katalisasi Pemberdayaan Masyarakat Desa. Januari 22-26.

Wardani, A., 2018. AKUNTABILITAS PENGELOLAAN KEUANGAN DESA DI DESA DENANYAR KECAMATAN JOMBANG KABUPATEN JOMBANG.

Wijaya, E., Anggraeni, R., Bachri, R., 2013. Desa Digital : Peluang untuk Mengoptimalkan Penyebarluasan Peraturan Perundang-Undangan di Indonesia. J. Din. Huk. 13, 7588. 